\title{
Sensitivity of Fomes annosus Fr. Cooke and Schizophyllum commune Fr. to air pollution with sulphur dioxide
}

\author{
ANDRZEJ GRZYWACZ
}

Agricultural Academy of Warsaw, Institute of Forest and Wood Protection, Poland (Received: December 14, 1972)

Abstract

\begin{abstract}
The sensivity of mycelium to sulphur dioxide polluting the air depends on its physiological activity. As measure of activity growth was adopted, in the sense of the function of dry weight and diametre of the colony, intensity of respiration, amino acids and nitrogen content in dry mycelial mass. The influence of $\mathrm{SO}_{2}$ on mycelium growth in dependence on its age and $\mathrm{pH}$ of substrate was also investigated.
\end{abstract}

\section{INTRODUCTION}

One of the most common, not only in Poland, and most dangerous in its effect, components of air pollution is sulphur dioxide. In industrial districts it is a specific and essential ecological factor exerting an influence on all the components of the forest as an ecosystem, including also fungi pathogenic to trees.

Disappearance of the following fungi from forests has been observed in industrial districts: Microsphera alphitoides Griff. et Maubl., Rhitisma acerinum (Pers.) Fr. (K ö ck, 1935), a number of species from the genera Melampsora, Melampsoridium, Cronartium, Puccinia, Pucciniastrum (Scheffer and Hedgcock, 1955; Heagle, 1969; Hibben and Stotzky, 1969) Cronartium flaccidium (Alb. et Sch.) Wint. (Linzon, 1958), Lophodermium juniperinum (Fr.) de Not. (Schönbeck, 1968). Diplocarpon rosae (Lib.) Wolf. and Histericum pulicare (Pers.) Rhem. are considered to be as sensitive to air pollution as are some lichens and epiphytic mosses so that they may serve as indices of its degree. The noxious influence of air pollution on mushrooms, mycorrhizal and air-borne fungi, those pathogenic to man and soil microfungi has also been demonstrated (Pachlewski, 1958; Hibben and Stotzky, 1961; Krutikow, 1969; D ubos, 1970). 
Among the fungi activated by industrial emmission may be quoted: Armillariella mellea Vahl. Karst. (Novak et al., 1957, J a nčařik, 1961; Kudela and Novakova, 1962; Darley and Middleton, 1966; Sierpiński, 1972; Grzywacz, 1973 a), Rhizosphaera kalkhoffii Bubák (Chiba and Tanaka, 1968), Lophodermium pinastri (Schrad.) Chevall. (Costonis and Sinclair, 1967), Hirschioporus abietinus (Dicks. ex Fr.) Donk. (Novak et al., 1957, J a n čařik, 1961; Grzywacz, 1973 b), Hirschioporus fusco-violaceus (Ehrenb. ex Fr.) Donk. (Sierpiński, 1970, Grzywacz, 1973 b) and Schizophyllum commune Fr., Nectria cinnabarina Fr., Stereum pini Fr. and other species of the genus Stereum devouring wood of deciduous tree species (J a nčařik, 1961; Grzyw a c z, 1973 b). In forests suffering from chronic air pollution the specific composition of the saprophytic fungal flora on the leaves changes (Manning, 1971). A number of studies, mainly experimental, concerning the influence of air pollution and fungal pathogens on crop plants in agriculture and gardening indicate that the interaction of fungi with air pollution is of synergic character ( $\mathrm{Yarwood}$ and Middleton, 1954; Brisley et al., 1959; Schönbeck, 1960, Saunders, 1966; Manning et al., 1969, 1970, 1971).

The disappearance of some and activation of other pathogenic fungal species under the influence of changes in the forest ecosystem due to the phytotoxic components of air pollution will become a new problem in forest protection.

The reaction of pathogenic fungi to $\mathrm{SO}_{2}$ in the air depends on many factors, mainly on the concentration, diurnal amplitude and seasonal variations of the concentration, on duration of exposure, composition of the vegetal cover and degree of damage to it caused by $\mathrm{SO}_{2}$, the topography of the area, climatic conditions, kind of forest habitats and sensitivity of the given pathogens.

The purpose of the present study was to examine whether the sensitivity of the mycelium to $\mathrm{SO}_{2}$ may be a significant factor decisive for the disappearance of the given species from the forests in industrial districts, and to establish the physiological conditionings of the sensitivity threshold to this phytotoxin.

\section{MATERIAL AND METHODS}

The mycelia were fumigated in an air-tight chamber with 6 compartments into which ventilators were introduced in order to ensure a uniform $\mathrm{SO}_{2}$ concentration. Appropriate concentrations were obtained by acting with sodium pyrosulphate aliquots and hydrochloric acid. The influence of $\mathrm{SO}_{2}$ on the mycelium was investigated at concentrations of $0.01,0.1,1,10,100$ and $1000 \mathrm{mg} / \mathrm{m}^{3}$, with time of exposure $30 \mathrm{~min}$, $1,6,12,24 \mathrm{~h}$ and $3,5,10,14$ and 20 days. Of the more than ten fungal 
species tested, pure cultures were chosen of the following: Schizophyllum commune Fr. as relatively resistant and rather common in avenues and in forests of the Upper Silesian Industrial District (Grzywacz, 1971, 1973 b) and Fomes annosus Fr. Cooke as sensitive to $\mathrm{SO}_{2}$ and disappearing from forest areas with polluted air (Grzywacz, $1973 \mathrm{a}, 1973 \mathrm{~b}$ ). The fungi were cultured on malt-agar medium, and in investigations on the influence of $\mathrm{SO}_{2}$ on the reaction of the medium, amino acids and total nitrogen content in the mycelium, as medium for the culture brewer's wort from barley malt was used. The cultures were kept under natural light at room temperature and 80 per cent relative air moisture. After closing of the compartments and switching on of the ventilators, the moisture inside was 96 per cent. Each variant of the experiments was replicated 10 times (10 mycelium colonies).

Respiration intensity measurements were performed on the mycelium in the closed system of a gas $\mathrm{CO}_{2}$ analyzer of Infralyt II type in unchanging laboratory conditions $\left(25.0^{\circ} \mathrm{C}\right.$, air flow velocity $\left.40 \mathrm{l} . / \mathrm{h}\right)$ in a dark chamber.

Amino acids were analyzed in an automatic, Carlo Erba type 3 A 27 amino acid analyzer according to the method described by Spa ckman, Stein and Moore in 1958. The extracts for analysis were prepared from powdered 10-day mycelium (6 days after fumigation) dried at $80^{\circ} \mathrm{C}$ (Whitaker, 1971).

\section{RESULTS AND DISCUSSION}

1. Influence of various $\mathrm{SO}_{2}$ concentrations and time of exposure on the growth of test fungal species

The investigations demonstrated that the $\mathrm{SO}_{2}$ influence on fungi depends on the concentration and the time of exposure to it, as has been reported earlier (Couey and U ota, 1961, Nelson and Backer 1962, Couey, 1965). It was found that fumigation (in the time period tested) with a $0.01 \mathrm{mg} / \mathrm{m}^{3} \mathrm{SO}_{2}$ concentration did not produce significant differences in the growth of the mycelium, and in a $0.1 \mathrm{mg} / \mathrm{m}^{3}$ concentration slightly stimulated growth. This was hardly noticeable when fumigation was short and statistically nonsignificant, but distinct when the treatment lasted 5 or more days. $\mathrm{SO}_{2}$ in 10,100 and $1000 \mathrm{mg} / \mathrm{m}^{3}$ concentrations inhibited growth in the species tested in various degrees. Schizophyllum commune still showed growth 20 days after fumigation at a $1000 \mathrm{mg} / \mathrm{m}^{3}$ concentration, whereas the mycelium of Fomes annosus exposed to the same ceased growing after 14 days.

A single $30 \mathrm{~min}$ fumigation at a 0.01 or $0.1 \mathrm{mg} / \mathrm{m}^{3}$ concentration did not produce any difference in mycelium growth, but with $1 \mathrm{mg} / \mathrm{m}^{3}$ of $\mathrm{SO}_{2}$ the difference was visible. When an equal concentration was used 
for fumigation, the growth was reduced proportionally to the time of exposure in the chamber (Fig. 1).

Sulphur dioxide stimulated linear growth of the hyphae when the concentration was low and the time short. This phenomenon is noticeable

$\%$ of weight dry mass control part

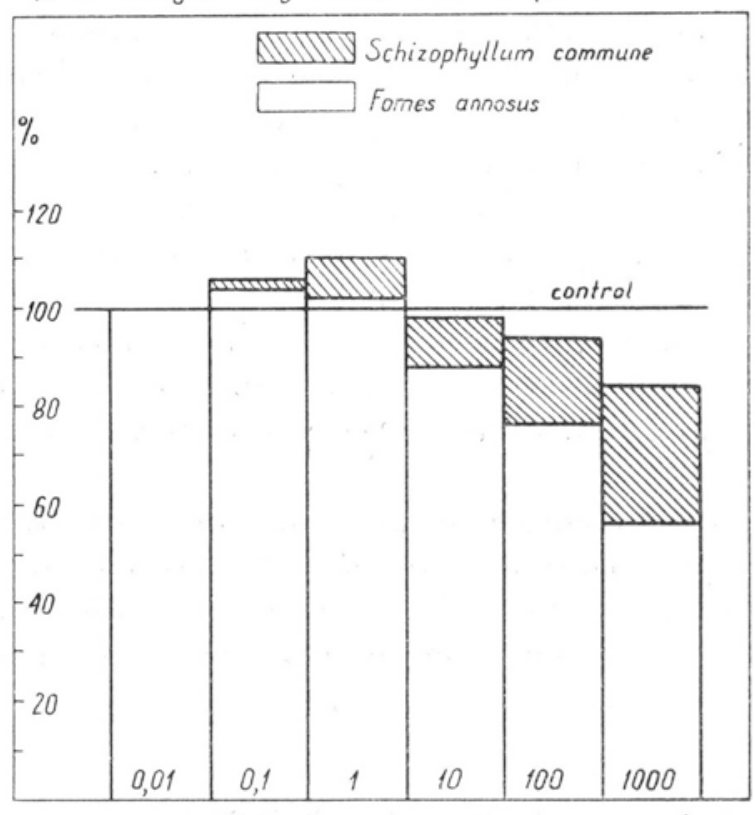

$\mathrm{SO}_{2}$ concentration in $\mathrm{mg} / \mathrm{m}^{3}$

Fig. 1. Influence of various $\mathrm{SO}_{2}$ concentrations on dry weight of mycelium, expressed as per cent of weight of control mycelium (exposure to fumigation 10 days)

in what is called escape of mycelium visualized in the graphic comparison of the colony diametre and the dry weight of the mycelium (Fig. 2).

Schizophyllum commune growing in an $\mathrm{SO}_{2}$-polluted atmosphere aged sooner and produced fruitbodies much earlier. After 10 days neither fruitbodies nor their primordia were found in the control group (20 slides), and in the fumigated group with $1 \mathrm{mg} / \mathrm{m}^{3} 25$ per cent of the colonies had fruitbodies and in the group fumigated with $100 \mathrm{mg} / \mathrm{m}^{3}$ 60 per cent. It results from the experiments that $\mathrm{SO}_{2}$ in low concentration stimulates the growth of vegetative mycelium, and in high concentration (10 and $100 \mathrm{mg} / \mathrm{m}^{3}$ ) fructification processes, while the amount of vegetative mycelium is considerably reduced.

Sulphur dioxide caused changes in the morphological structure of the mycelium colonies. Mycelium fumigated with $10 \mathrm{mg} / \mathrm{m}^{3}$ and higher concentrations, after 14 days of this treatment showed a dense compact 
arrangement of hyphae, and lost its fluffy apperance. After long-lasting exposure to $\mathrm{SO}_{2}$, brown necrotic regular spots appeared on the mycelium surface. This phenomenon was observed in both species examined.

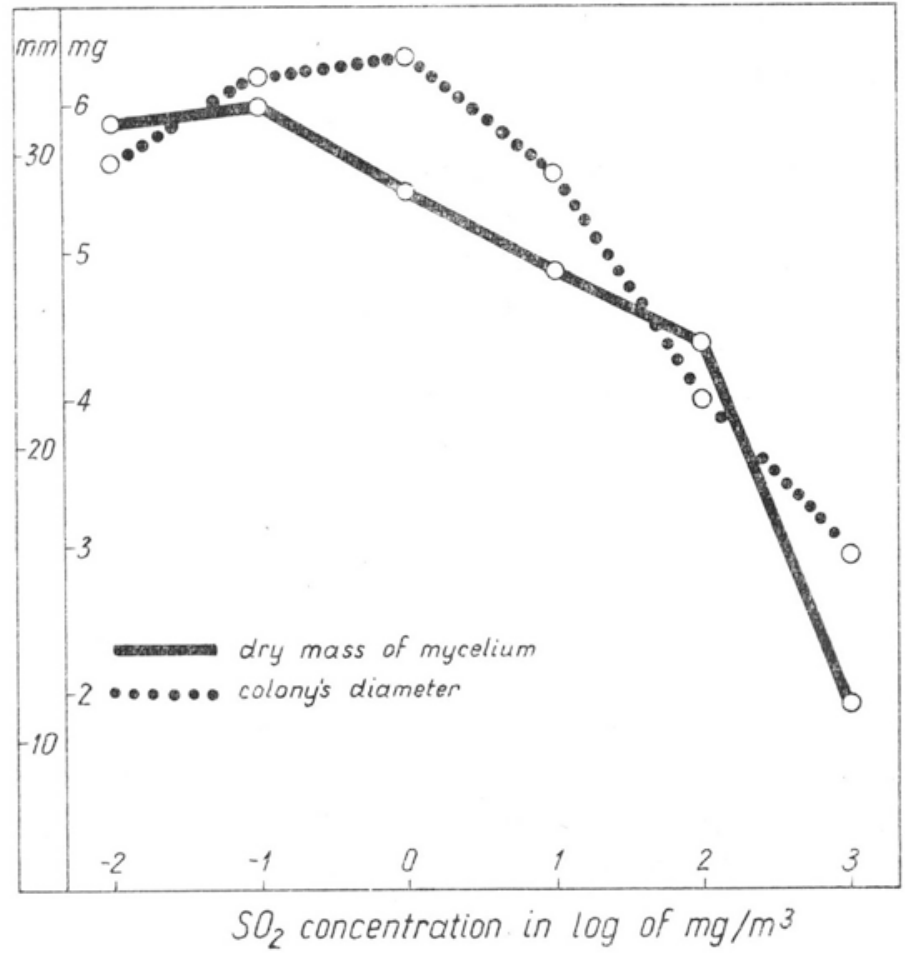

Fig. 2. Influence of 3-day fumigation with $\mathrm{SO}_{2}$ on dry weight and diametre of Fomes annosus mycelium colony

Thus, $\mathrm{SO}_{2}$ in concentrations of $0.1,0.5$ and $1.0 \mathrm{mg} / \mathrm{m}^{3}$ ( Godzik and Piskornik, 1969, 1970) noxious to most green plants only caused growth inhibition in the tested fungi and for S. commune was a stimulator of growth and fructificaton. Death of mycelium occurred only at high concentrations $\left(100\right.$ and $\left.1000 \mathrm{mg} / \mathrm{m}^{3}\right)$ not found in nature. It should be stressed here that the results concerned only a relatively short time period (20 days).

2. Influence of $\mathrm{SO}_{2}$ on mycelium growth in dependence on its age

The mycelium was most sensitive to $\mathrm{SO}_{2}$ at the moment of most intensive growth. At this period the intensity of respiration of the mycelium is very high, and this causes an increased inhalation of air together with the sulphur dioxide polluting it into the hyphae. The relatively greater amount of $\mathrm{SO}_{2}$ absorbed, as compared to the cell mass in the mycelium growing most intensively, enhances the toxic effect 
of $\mathrm{SO}_{2}$. The youngest and oldest mycelia, in which the intensity of metabolic processes is relatively low, showed much lower sensitivity to $\mathrm{SO}_{2}$. The age of the mycelium is understood as time from its inoculation into the medium to the end of the experiment. After the end of short-lasting fumigation growth was somewhat inhibited for a time, but this was followed by accelerated growth and even regeneration of the mycelium (renewed growth after its complete inhibition). In this experiment, on the 12-14th day of mycelium growth (after the culmination of daily increment of the mycelial mass in the control), a new increase of daily growth increments was observed in the fumigated group.

Change in the sensitivity of the mycelium to $\mathrm{SO}_{2}$ depending on age is not a specific phenomenon for the action of this phytotoxin. Similar dependences were observed in treatment of the mycelium with other toxic substances, particularly with fungicides (Damaschke and $\mathrm{Ba}-$ cker, 1965).

\section{Influence on respiration of fungi}

Fumigation of mycelium for several days with sulphur dioxide causes changes in the respiration intensity. Concentrations of $0.1,1,10$ and $100 \mathrm{SO}_{2} / \mathrm{m}^{3}$ stimulated respiration in $S$. commune as compared to that in nonfumigated mycelium.. Only a concentration as high as $1000 \mathrm{mg} / \mathrm{m}^{3}$ produced a fall in respiration intensity. On the other hand, the mycelium of $F$. annosus showed a stimulation of respiration only at $0.1 \mathrm{mg} / \mathrm{m}^{3} \mathrm{SO}_{2}$ concentration. Higher doses caused a fall of respiration intensity. When

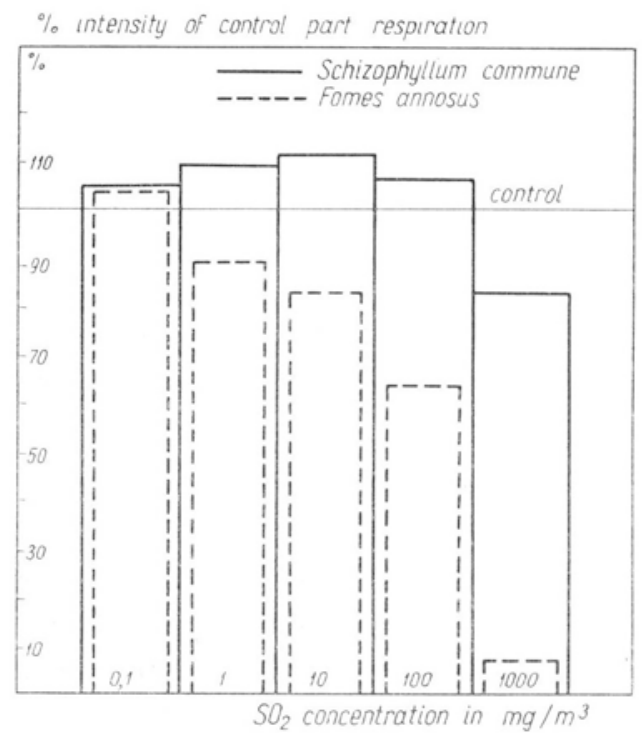

Fig. 3. Respiration intensity of mycelium exposed to $\mathrm{SO}_{2}$ as compared to that of control mycelium 


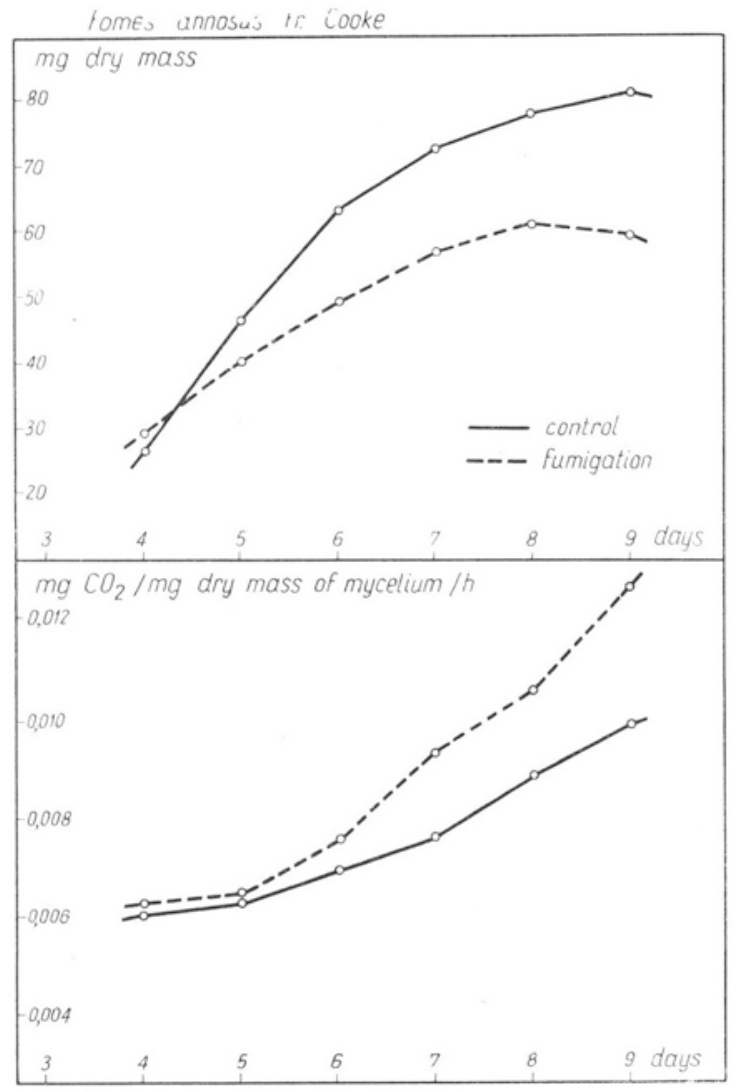

Fig. 4. Influence of $\mathrm{SO}_{2}$ on dry weight and respiration intensity of mycelium depending on its age $\left(1 \mathrm{mg} / \mathrm{m}^{3}\right)$

$1000 \mathrm{mg} / \mathrm{m}^{3}$ was applied, respiration of $F$. annosus decreased to 7.8 per cent of that of the control mycelium (Fig. 3).

By performing measurements on each of six successive days of fumigation of $F$. annosus mycelium with $1 \mathrm{mg} / \mathrm{m}^{3} \mathrm{SO}_{2}$ it was demonstrated that stimulation of respiration due to the action of this substance increases with the age of the mycelium. Enhanced respiration intensity points to the occurrence of detoxification processes in the mycelium. In the end stages of the experiment the dry weight of the mycelium decreased, as compared with the previous day, owing to the prevalence of dissimilation processes over those of assimilation (Fig. 4).

4. Influence on amino acids content in mycelium

Investigation of amino acids content in dry mycelial mass of fungal species submitted to fumigation with $\mathrm{SO}_{2}$ showed a considerable fall of their content with increasing $\mathrm{SO}_{2}$ concentration. This substance acts on 
Table 1

Amino acids content in Fomes annosus Fr. Cooke mycelium subjected to fumigation with $\mathrm{SO}_{2}$ of various concentrations

\begin{tabular}{|c|c|c|c|c|}
\hline \multirow{3}{*}{ Amino acids } & \multicolumn{4}{|c|}{ Amino acids content in $1 \mathrm{~g}$ dry mycelial mass, $\mu$ moles } \\
\hline & \multirow{2}{*}{ control } & \multicolumn{3}{|c|}{$\mathrm{SO}_{2} \mathrm{mg} / \mathrm{m}^{3}$} \\
\hline & & 1 & 10 & 100 \\
\hline aspartic acid & 154.00 & 119.42 & 59.14 & 56.00 \\
\hline threonine & 69.57 & 47.65 & 20.61 & 23.54 \\
\hline serine & 182.85 & 105.15 & 49.28 & 46.85 \\
\hline proline & 72.06 & 46.02 & 26.75 & 20.99 \\
\hline glutamic acid & + & + & + & + \\
\hline glycine & 157.25 & 119.74 & 86.34 & 86.40 \\
\hline alanine & 162.18 & 111.04 & 47.55 & 41.15 \\
\hline cystine & + & + & + & + \\
\hline valine & 102.53 & 65.02 & 36.03 & 32.13 \\
\hline methionine & 32.51 & 26.37 & 24.83 & 17.86 \\
\hline isoleucine & 95.36 & 82.82 & 39.36 & 31.62 \\
\hline leucine & 113.34 & 62.34 & 35.97 & 35.90 \\
\hline tyrosine & + & + & + & + \\
\hline phenylalanine & 46.63 & 36.61 & 17.08 & 17.09 \\
\hline lysine & 59.71 & 34.37 & 13.38 & 20.22 \\
\hline histidine & 26.24 & + & + & + \\
\hline arginine & 47.04 & 30.78 & + & + \\
\hline Total amino acids & 1320.26 & 861.09 & 453.89 & 432.18 \\
\hline$\%$ & 100.0 & 65.2 & 34.3 & 32.7 \\
\hline
\end{tabular}

+ trace amounts were found

the organism as a whole, therefore it does not show any special influence on any specific amino acid. No amino acids were found to be unsusceptible. The greatest decrease as compared with control values was noted in histidine and arginine in both fungal species, and in $F$. annosus also in alanine and serine. Histidine was detected both in F. annosus and $S$. commune only in nonfumigated mycelium (Tables 1,2 ). In that exposed to $1 \mathrm{mg} / \mathrm{m}^{3} \mathrm{SO}_{2}$ only trace amounts could be found. The control mycelium of $F$. annosus contained about two times less amino acids in $1 \mathrm{~g}$ of dry matter than the $S$. commune mycelium, thus, in this species the process of amino acids degradation was much more intensive.

\section{Influence on total nitrogen content in mycelium}

Exposure to sulphur dioxide caused changes in total nitrogen content in the mycelium mainly by reducing the amino acids content. The increase, and afterwards fall, in nitrogen content with increasing $\mathrm{SO}_{2}$ 
Table 2

Amino acids content in Schizophyllum commune Fr. mycelium fumigated with various $\mathrm{SO}_{2}$ concentrations

\begin{tabular}{|c|c|c|c|c|}
\hline \multirow{3}{*}{ Amino acids } & \multicolumn{4}{|c|}{ Amino acids content in $1 \mathrm{~g}$ dry mycelial mass, $\mu$ moles } \\
\hline & \multirow{2}{*}{ control } & \multicolumn{3}{|c|}{$\mathrm{SO}_{2} \mathrm{mg} / \mathrm{m}^{3}$} \\
\hline & & 1 & 10 & 100 \\
\hline aspartic acid & 40.25 & 38.72 & 37.20 & 31.84 \\
\hline threonine & 30.75 & 30.34 & 29.47 & 14.24 \\
\hline serine & 70.50 & 72.96 & 56.70 & 28.42 \\
\hline proline & 30.88 & 32.51 & 29.63 & 18.08 \\
\hline glutamic acid & + & + & + & + \\
\hline glycine & 140.51 & 161.22 & 122.37 & 62.72 \\
\hline alanine & 35.20 & 23.46 & 27.46 & 13.25 \\
\hline cystine & + & + & + & + \\
\hline valine & 22.08 & 20.90 & 16.42 & 7.90 \\
\hline methionine & 33.82 & 22.92 & 19.90 & 12.03 \\
\hline isoleucine & 52.78 & 46.78 & 45.95 & 31.94 \\
\hline leucine & 60.03 & 64.00 & 45.06 & 26.43 \\
\hline tyrosine & + & + & + & + \\
\hline phenylalanine & 13.44 & 22.40 & 17.06 & 8.22 \\
\hline lysine & 21.98 & 21.89 & 14.40 & 9.60 \\
\hline histidine & 38.75 & + & + & + \\
\hline arginine & 26.34 & 17.65 & 22.40 & + \\
\hline Total amino acids & 617.27 & 575.75 & 484.02 & 264.67 \\
\hline$\%$ & 100.0 & 93.2 & 78.4 & 42.8 \\
\hline
\end{tabular}

+ trace amounts were found

Table 3

Percentual total nitrogen content in dry mycelial mass after fumigation with various $\mathrm{SO}_{2}$ concentration

\begin{tabular}{c|c|c}
\hline $\begin{array}{c}\text { Concentration } \\
\mathrm{SO}_{2} \mathrm{mg} / \mathrm{m}^{3}\end{array}$ & $\begin{array}{c}\text { Schizophyllum } \\
\text { commune }\end{array}$ & $\begin{array}{c}\text { Fomes } \\
\text { annosus }\end{array}$ \\
\hline control & 1.71 & 4.44 \\
0.1 & 1.72 & 4.47 \\
1 & 1.82 & 4.56 \\
10 & 1.63 & 4.20 \\
100 & 1.57 & 4.04 \\
\hline
\end{tabular}

concentration had a different and slower course than the changes in amino acids content (Table 3). Probably the composition of other nitrogen compounds did not change under the action of $\mathrm{SO}_{2}$ as much as did proteins. This would probably refer to such a chemically relatively stable substance as chitin (linear acetylglucosamine polymer). The reduced 
content of nitrogen compounds in the fumigated mycelium cells produced a relative increase of the contribution of substances composing the cell walls to $1 \mathrm{~g}$ of dry weight of the mycelium. Hence, the total nitrogen content in the fumigated mycelium did not probably change as much as did the amino acids content. The problem whether the cell walls thicken in mycelium exposed to fumigation, as a defence reaction of the fungus to conditions unfavourable to growth in the environment requires further elucidation.

\section{Influence on reaction of medium}

Sulphur dioxide changes the reaction of the medium by acidifying it and by changing the reaction in the mycelium cells. This leads to disturbances of the metabolic processes. The following processes affect the $\mathrm{pH}$ of the medium: absorption of cations and anions in the growth

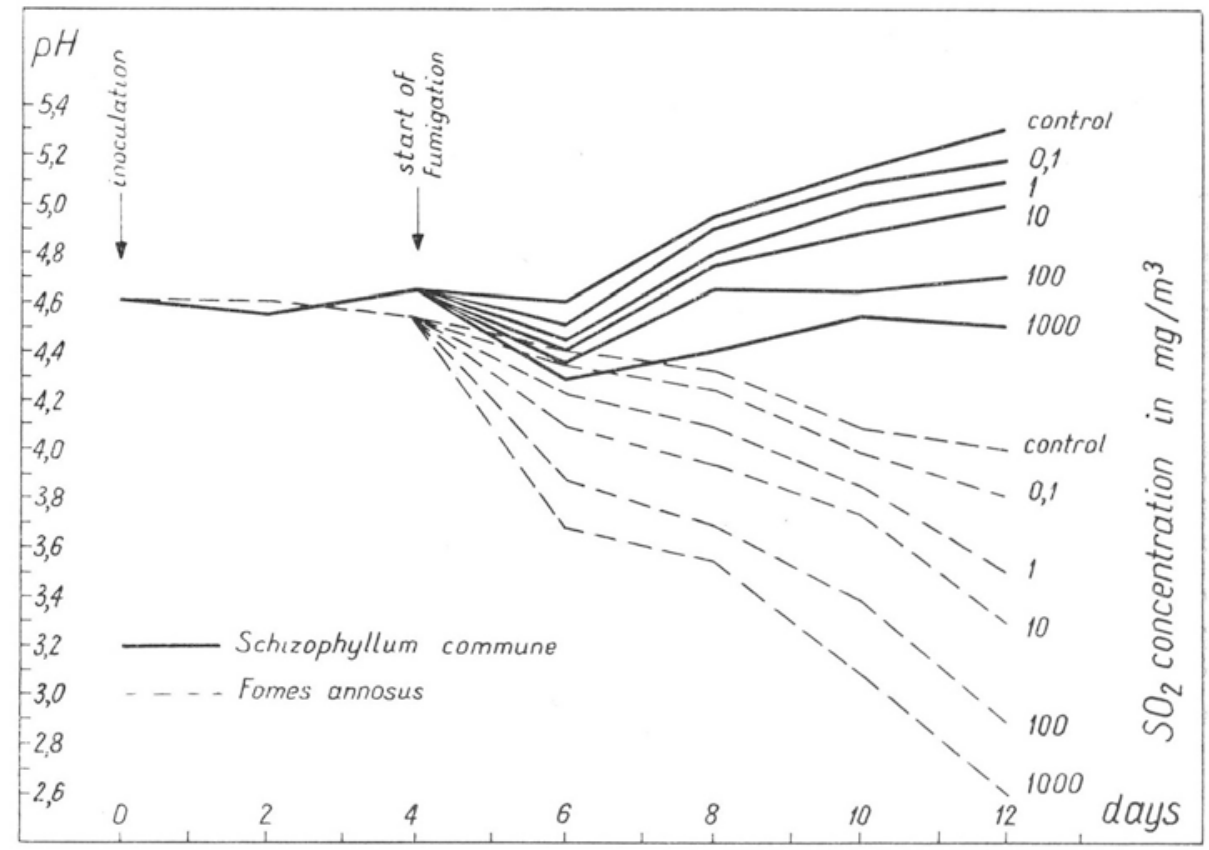

Fig. 5. Changes in $\mathrm{pH}$ of medium under the influence of fumigation in cultures of the species tested

process of the fungi, formation of acids from neutral metabolites and of bases, mainly from amino acids and proteins. Changes in $\mathrm{pH}$ are resultants of all these processes.

Most important are the $\mathrm{pH}$ changes due to disturbance of metabolic processes after fumigation, since changes of $\mathrm{pH}$ in medium without mycelium are only slight (when $\mathrm{SO}_{2}$ particles fall on the medium surface 
freely). Five days after exposure to $\mathrm{SO}_{2}$ in a concentration of $100 \mathrm{mg} / \mathrm{m}^{3}$ the medium changed only by $0.2 \mathrm{pH}$ and at lower concentrations still less.

F. annosus mycelium acidified the medium in normal conditions. This process is markedly accelerated when the mycelium grows in a $\mathrm{SO}_{2}$-polluted atmosphere. As early as after 2 days of fumigation (6th day of mycelium growth) the medium in Petri dishes exposed to $100 \mathrm{mg} / \mathrm{m}^{3}$ showed $\mathrm{pH} 3.8$, whereas the $\mathrm{pH}$ of the control was 4.3 . After further exposure the difference became wider. Fomes annosus exhibits but slight buffer properties, and is uncapable to counteract the acidification of the medium by $\mathrm{SO}_{2}$ (Fig. 5).

Schizophyllum commune reacts differently to changes in $\mathrm{pH}$ of the medium due to $\mathrm{SO}_{2}$. It has buffer qualities and can maintain $\mathrm{pH}$ almost unchanged even when exposed to high concentration of the gas. Nonfumigated mycelium raised the $\mathrm{pH}$ as it grew to the optimal value of 6.0. Exposure of the mycelium to concentrations as high as 100 and $1000 \mathrm{mg} / \mathrm{m}^{3} \mathrm{SO}_{2}$ did not after 9 days lower the acidity below the initial $\mathrm{pH}$ of the medium.

The considerably higher respiration intensity depends on the content of protein compounds in the mycelial cells of $F$. annosus, as compared to that of Schizophyllum commune mycelium, causes a more active $\mathrm{SO}_{2}$ adsorption from the polluted air, and this in turn produces intensive disturbances in metabolic processes responsible for changes in the $\mathrm{pH}$ of the medium.

\section{CONCLUSIONS}

1. The reduction in growth of the mycelium fumigated with $\mathrm{SO}_{2}$ is proportional to the concentration of the gas and the time of exposure to it in the fumigation chamber.

2. The mycelium is most sensitive at the moment of its most intensive growth.

3. Low $\mathrm{SO}_{2}$ concentrations stimulate linear growth of the hyphae, whereas high concentrations inhibit it and cause quicker ageing of the mycelium with necrotic colour changes.

4. Sulphur dioxide produces morphological changes in the mycelial colony and disturbs fructification processes.

5. Mycelium growing in an atmosphere polluted with $\mathrm{SO}_{2}$ shows changes in respiration intensity. Low concentrations stimulate and high ones inhibt this process. The extent of the respiratory disturbances due to $\mathrm{SO}_{2}$ changes with the age of the mycelium.

6. Under the influence of fumigation with $\mathrm{SO}_{2}$ the amino acids content changes in the mycelium, and these changes become wider with higher 
concentrations. The greatest decrease was noted in histidine, and arginine, and also in alanine and serine content.

7. The total nitrogen content in dry mycelial mass is decreased by exposure to $\mathrm{SO}_{2}$.

8. Fumigation with $\mathrm{SO}_{2}$ influences the changes in medium $\mathrm{pH}$. The species tested differ in buffer qualities which counteract the acidification of the medium by $\mathrm{SO}_{2}$.

9. The sensitivity of the tested fungal species to $\mathrm{SO}_{2}$ depends on their physiological activity. The higher the protein content in the hyphal cells and the higher the respiration intensity, the more sensitive is the species to $\mathrm{SO}_{2}$.

The author is indebted to Dr. M a rek Szczy g i e 1 of the Institute of Animal Physiology, Academy of Agriculture, Warsaw for performing the analyses of amino acids.

\section{REFERENCES}

Brisley H. R., Davis C. R., B ooth I. A., 1959. Sulfur dioxide fumigation of cotton with special reference to its effect on yield, Agron. J. 51: 77-80.

$\mathrm{Chiba}$ O., Tanaka K., 1968. The effect of sulphur dioxide on the development of pine needle caused by Rhizosphera kalkhoffii Bubák, J. Jap. For. Soc. 50(5): 135-139.

Costonis A. C., Sinclair W. A., 1967. Effects of Lophodermium pinastri and Pullularia pullulans on healthy and ozone-injury needles of Pinus strobus, Phytopathology 57(8): 807, Abstr.

C o u e y H. M., U ot a M., 1961. Effect of concentration, exposure time, temperature and relative humidity on the toxicity of sulfur dioxide to the spores of $\mathrm{BO}$ trytis cinerea, Phytopathology 51(12): 815-819.

Couey H. M., 1965. Inhibition of germination of Alternaria spores by sulfur dioxide under various moisture conditions, Phytopathology 55(5): 525-527.

D a m a s chke K., B a cker G., 1965. Rhythmen des Sauerstoffverbrauchs von Basidiomycetes, Holz und Organismen (1): 275-290.

Darley E. P., Middleton J. T., 1966. Problems of air pollution in plant pathology, Ann. Rev. Phytopath. 4: 102-118.

D u b os René, 1970, Człowiek, środowisko, adaptacja, PZWL, Warszawa.

Godzik S., Piskornik Z., 1969. Oddziaływanie zanieczyszczeń powietrza na rośliny, Wiad. Bot. (4): 239-248.

Godzik S., Piskornik Z., 1970. Oddziaływanie zanieczyszczeń powietrza na rośliny cz. II, Wiad. Bot. (2): 91-102.

Grzywacz A., 1971. Wpływ przemysłowych zanieczyszczeń powietrza na patogeniczne grzyby drzew leśnych, Sylwan (6): 55-62.

Grzy wa c z A., 1973a. Występowanie niektórych grzybów chorobotwórczych w lasach okręgów przemysłowych Polski, Sylwan (w druku).

Grzywacz A., 1973b. Występowanie grzybów chorobotwórczych w drzewostanach Nadleśnictwa Panewnik objętych wpływem zanieczyszczeń powietrza, Zesz. Nauk. Akad. Rol. w Warszawie (w druku). 
H e a g le A. S., 1970. Effect of low-level ozone fumigation on crown rust of oats, Phytopathology 60(2): 252-254.

Hibben C. R., Stotzky G., 1969. Effect of ozone on the germination of fungus spores, Can. J. Microbiol. 15(10): 1187-1196.

J a n čă̌ik V., 1961, Vyskyt drevokaznych hub u kouřem poškozovane oblasti Krušnych hor, Lesnictvi 7: 667-692.

Krutikow A., 1969. Zmiany w biocenozie lasów Krakowskiego Okręgu Przemysłowego, Las Polski 13/14: 23-24.

Köck G., 1935. Eichenmehltan und Rauchgasschaden, Z. f. Pflancenkrannkh. 45: 44-45, R.A.M. 1935, p. 406.

Ku dela M., Nováková E., 1962. Lesni škudei a škody zvěři u lesich poškozovanych kouřem, Lesnictvi 8(6): 493-502.

Linzon S. N., 1958. The influence of smelter fumes on growth of white pine in the Sudbury region, Ontario Dep. Lands Forests Ontario Dep. Mines, Toronto, $45 \mathrm{pp}$.

Manning W. J., Feder W. A., Perkins J., Glickman H., 1969. Ozone injury and infection of potato leaves by Botrytis cinerea, Plant Disease Rep. 53(9): $691-693$.

Manning W. J., Feder W. A., Perkins J., 1970. Ozone injury increase infection of Geranium leaves by Botrytis cinerea, Phytopathology 60(4): 669-670.

Manning W. J., Feder W. A., Perkins J., 1971. Effect of low leaves of ozone on growth and susceptibilty of cabage plants to Fusarium oxysporum f. sp. conglutinans, Plant Disease Rep. 54(1): 47-49.

Manning W. J., 1971. Influence of limnestone dust on foliar disease incidence and leaf surface microflora of three native plants, Phytopathology 61(2): 131, Abstr.

Nelson K. E., Backer G. A., 1962. Effect of storage environment on quality of table grapes and on requirements of sulfur dioxide fumigant program, Phytopathology 51(8): 745-746.

Novak W., J ančařik V., J ermanova H., 1957. Hlavni živocisni škudci a hubove choroby $\mathrm{v}$ oblasti Krušnych hor, Zpravy VULH, 1: 44-46.

Pachlewski R., 1958. Badania mikotrofizmu naturalnych zespołów roślinnych na hałdach górniczych w Knurowie i Gliwicach na Górnym Sląsku, Prace IBL, 182: 173-209.

Scheffer T. C., Hedgcock G. C., 1955. Injury to Northwestern forest trees by sulfur dioxide from smelters, USDA Tech. Bull. 1117, 49 pp., For. Abstr., 1955, No. 1700 .

Schönbeck H., 1960. Beobachtung zur Frage des Einflusses von industriellen Immissionen auf die Krankheitsbereitschaft der Pflanze, Landesanstalt f. Bodennutzungsschutz des Landes Nordrhein-Westfalen, 89-98.

$\mathrm{Schön} \mathrm{beck} \mathrm{H.,} \mathrm{1968.} \mathrm{Proceedings} \mathrm{of} \mathrm{the} \mathrm{First} \mathrm{European} \mathrm{Congress} \mathrm{on} \mathrm{the} \mathrm{Influence}$ of Air Pollution on Plants and Animals. Wageningen, 237-241 (in discussion).

Sierpiński Z., 1970. Gospodarcze znaczenie szkodliwych owadów w drzewostanach sosnowych objętych chronicznym działaniem przemysłowych zanieczyszczeń powietrza, Sylwan (6): 59-71.

Sierpiński Z., 1972, Znaczenie gospodarcze szkodników wtórnych w drzewostanach sosnowych znajdujących się w zasięgu chronicznego działania przemysłu, Prace IBL, 410: 85-113.

Spackman D. H., Stein W. H., M o or e F., 1958. Automatic recording aparatus for use in the chromatografy of amino acid, Analit. Chem. 30: 1190-1206. 
Whitaker A., 1971. Amino acid transport in Penicillium griseofulvum, Trans. Brit. Mycol. Soc. 56: 353-369.

Yerwood C. E., Middleton J. T., 1954. Smog injury and rust infection, Plant Physiol. 29: 393-395.

Author's adress: Andrzej Grzywacz Agricultural Academy of Warsaw, Institute of Forest and Wood Protection, Rakowiecka 26/30, 02-528 Warsaw, Poland

\section{Wrażliwość Fomes annosus Fr. Cooke i Schizophyllum commune Fr. na dwutlenek siarki zanieczyszczajacy powietrze}

\section{Streszczenie}

Zanik pewnych i aktywizacja innych gatunków grzybów patogenicznych drzew pod wpływem zmian w ekosystemach leśnych spowodowanych fitotoksycznymi składnikami zanieczyszczeń powietrza stanowi nowy problem ochrony lasu. Reakcje grzybów na $\mathrm{SO}_{2}$, główny składnik zanieczyszczeń, zależą od wielu czynników, między innymi od ich wrażliwości.

W pracy badano wpływ $\mathrm{SO}_{2}$ na wzrost grzybni Fomes annosus i Schizophyllum commune w warunkach laboratoryjnych, stosując różne koncentracje i czas działania. Stwierdzono, że zmniejszony wzrost grzybni fumigowanej $\mathrm{SO}_{2}$ jest odwrotnie proporcjonalny od koncentracji i czasu ekspozycji w kamerze. Najbardziej wrażliwa jest grzybnia w momencie najintensywniejszego wzrostu. $\mathrm{SO}_{2}$ powoduje zmiany morfologiczne kolonii grzybni, zaburzenia w procesach fruktyfikacji, szybsze starzenie się i powstawanie nekrotycznych przebarwień. Niskie stężenia stymulują liniowy wzrost strzępek grzybni. Bardzo wysokie stężenia nie występujące już w przyrodzie $\left(100\right.$ i $1000 \mathrm{mg} / \mathrm{m}^{3}$ ) nie spowodowały jeszcze całkowitego zabicia grzybni po 20-dniowej fumigacji, dotyczy to względnie odpornego gatunku, jakim jest S. commune.

Niskie stężenia symulują, wysokie inhibują procesy oddychania. Wielkość zmian intensywności oddychania pod wpływem $\mathrm{SO}_{2}$ zmienia się wraz $\mathrm{z}$ wiekiem grzybni. Dwutlenek siarki powoduje spadek zawartości aminokwasów w grzybni, pogłębiający się w miarę wzrostu jego stężenia. Największemu ubytkowi ulegają: histidyna, arginina, alanina i seryna. Ulega obniżeniu zawartość azotu ogólnego w suchej masie grzybni. Badane gatunki grzybów posiadają różne zdolności buforowe, pozwalające na przeciwdziałanie wzrostowi kwasowości pożywki pod wpływem fumigacji.

Badane gatunki wykazały duże różnice we wrażliwości na $\mathrm{SO}_{2}$, wypływa to z ich aktywności fizjologicznej. Fakt ten pozwala wytłumaczyć zanik Fomes annasus oraz aktywizację Schizophyllum commune w lasach okręgów przemysłowych.

Instytut Ochrony Lasu i Drewna Akademia Rolnicza, Warszawa 12, ul. Rakowiecka 26/30 